\title{
MANAJEMEN KESELAMATAN DAN KESEHATAN KERJA DALAM MEWUJUDKAN ZERO ACCIDENT
}

\author{
Meirinawati \\ Jurusan Administrasi Publik, Fakultas Ilmu Sosial dan Hukum, Universitas Negeri Surabaya, meirinawati@unesa.ac.id
}

\section{Indah Prabawati}

Jurusan Administrasi Publik, Fakultas Ilmu Sosial dan Hukum, Universitas Negeri Surabaya, indahprabawati@unesa.ac.id

\begin{abstract}
Abstrak
Pada sektor industri, SDM merupakan unsur penting yang merupakan asset dan unsur penting yang berfungsi sebagai modal non material yang dapat diwujudkan menjadi potensi nyata secara fisik dan non fisik dalam mewujudkan eksistensi organisasi. Realitas yang terjadi bahwa perlindungan keselamatan dan kesehatan kerja sering diabaikan khususnya oleh mereka yang cenderung mencari keuntungan semata. Jika pekerja mengalami kecelakaan kerja maupun terkena penyakit akibat kerja maka instansi dengan mudahnya mengganti dengan pekerja baru. Dalam rangka memberikan perlindungan bagi tenaga kerja, maka suatu instansi perlu memperhatikan keselamatan dan kesehatan tenaga kerja dengan menerapkan Manajemen Keselamatan dan Kesehatan Kerja (K3).
\end{abstract}

Kata Kunci: Manajemen K3, zero accident

\begin{abstract}
In the industrial sector, human resources is an important asset and element that serves as a non-material capital that can be realized into physical and non physical potential in realizing the existence of the organization. Protection of occupational safety and health is often ignored, especially by those who tend to seek profit only. If a worker has an accident or a work-related illness then the agency simply replaces it with a new worker. In order to provide protection for the workforce, an agency needs to pay attention to the safety and health of the workforce by implementing Occupational Safety and Health Management.
\end{abstract}

Keywords: Occupational Safety and Health Management, Zero Accident

\section{PENDAHULUAN}

Indonesia tidak dapat menghindari persaingan bebas antar negara ketika termasuk dalam Masyarakat Ekonomi Asean (MEA). Pada era MEA, terdapat berbagai persaingan terutama yang terkait dengan lapangan pekerjaan. Penyediaan lapangan pekerjaan biasanya mengikuti perkembangan ekonomi yang sedang berlangsung. Perkembangan ekonomi pada awalnya lebih banyak penduduk yang bekerja di sektor pertanian, sejalan dengan perkembangan ekonomi bertransformasi menuju lapangan pekerjaan yang lebih kompleks yaitu sektor industri.

Pada sektor industri, SDM merupakan unsur penting yang merupakan asset dan unsur penting yang berfungsi sebagai modal non material yang dapat diwujudkan menjadi potensi nyata secara fisik dan non fisik dalam mewujudkan eksistensi organisasi. Hal ini disebabkan SDM mempunyai kemampuan dan keahlian serta kepribadian yang sesuai dengan company personality di tiap instansi sehingga memerlukan pengelolaan (manajemen) SDM. Manajemen SDM bukan merupakan hal yang mudah, karena sarana dan prasarana harus tersedia untuk mewujudkan SDM yang berkualitas. Manfaat MSDM tidak hanya dirasakan bagi instansi atau perusahaan tetapi juga bias dirasakan bagi tenaga kerja. Menurut Yani (2012), manfaat MSDM bagi instansi atau perusahaan adalah sebagai berikut:

1. Instansi atau perusahaan akan mempunyai sistem informasi SDM.

2. Instansi atau perusahaan akan memiliki hasil analisis jabatan.

3. Instansi atau perusahaan akan memiliki kemampuan dalam membuat dan menentukan perencanaan SDM.

4. Instansi atau perusahaan akan mampu meningkatkan efisiensi dan efektifitas pengadaan dan seleksi tenaga kerja.

5. Instansi atau perusahaan akan dapat melaksanakan pelatihan secara efektif dan efisien.

6. Instansi atau perusahaan akan dapat melaksanakan penilaian kerja secara efisien dan efektif.

7. Instansi dan perusahaan akan dapat melakukan program pembinaan karir. 
8. Instansi atau perusahaan dapat menyusun tingkat upah (gaji) dan mengatur kompensasi lainnya.

Sedangkan menurut Nawawi dalam Yani (2012), manfaat MSDM bagi tenaga kerja adalah sebagai berikut:

1. Pekerja memperoleh rasa aman dan puas dalam bekerja.

2. Pekerja memperoleh jaminan keselamatan dan kesehatan kerja.

3. Mempermudah pekerja memperoleh keadilan dari perlakuan yang tidak menguntungkan.

4. Pekerja memperoleh penilaian karya yang objektif.

5. Para pekerja melalui manajemen akan memperoleh gaji/upah dan pembagian keuntungan/manfaat lainnya..

Sadar akan pentingnya SDM dalam sebuah instansi pemerintah mengatur dalam Peraturan Pemerintah Pengganti Undang-Undang No. 3 tahun 2000, yang berisi bahwa pembangunan ketenagakerjaan bertujuan untuk:

1. Memberdayakan dan mendayagunakan tenaga kerja secara optimal

2. Menciptakan pemerataan kesempatan kerja dan penyediaan tenaga kerja yang sesuai dengan kebutuhan pembangunan nasional.

3. Memberikan perlindungan bagi tenaga kerja dalam mewujudkan kesejahteraannya.

4. Meningkatkan kesejahteraan tenaga kerja dan keluarga (Sedarmayanti, 2007:6).

Sejalan dengan hal tersebut, dalam rangka memberikan perlindungan bagi tenaga kerja, maka suatu instansi perlu memperhatikan keselamatan dan kesehatan tenaga kerja. Hal ini menuntut penggerak pada sektor industri untuk menerapkan Manajemen Keselamatan dan Kesehatan Kerja (K3).

Adanya Manajemen K3 dilatarbelakangi oleh realitas yang terjadi bahwa perlindungan keselamatan dan kesehatan kerja sering diabaikan khususnya oleh mereka yang cenderung mencari keuntungan semata. Jika pekerja mengalami kecelakaan kerja atau tidak mampu bekerja, maka instansi dengan mudahnya mengganti dengan pekerja baru (Ramli, 2009).

\section{METODE}

Penulisan artikel ini menggunakan metode studi literatur. Studi literatur merupakan metode penelusuran informasi dari berbagai sumber tertulis, bisa dari berbagai buku, arsip, majalah, artikel, dan jurnal, atau dokumen lain yang sesuai dengan pokok bahasan yang dikaji sehingga informasi yang didapat dari studi literatur dijadikan rujukan untuk memperkuat argumentasi.

\section{HASIL DAN PEMBAHASAN \\ Pengertian Keselamatan dan Kesehatan Kerja}

Manajemen Keselamatan dan Kesehatan Kerja merupakan konsep pengelolaan K3 yang sistematis dan komprehensif dalam suatu sistem manajemen yang utuh melalui proses perencanaan, penerapan, pengukuran dan pengawasan (Ramli, 2009). Adapun pengertian keselamatan kerja menurut Sumakmur dalam Yani (2012) adalah keselamatan yang bertalian dengan mesin, peralatan alat kerja, bahan serta proses pengolahannya, landasan tempat kerja dan lingkungannya serta cara-cara melaksanakan pekerjaan. Sedangkan pengertian keselamatan kerja menurut Yani (2012) yaitu keselamatan yang berhubungan dengan aktivitas kerja manusia baik pada industri manufaktur, yang melibatkan mesin, peralatan, penanganan material, pesawat uap, bejana bertekanan, alat kerja, bahan dan proses pengolahannya, landasan tempat kerja dan lingkungannya serta cara-cara melakukan pekerjaan, maupun industry jasa, yang melibatkan peralatan berteknologi canggih, seperti lift, escalator, peralatan pembersih gedung, sarana transportasi, dan lain-lain. Keselamatan kerja menurut Magginson dalam Mangkunegara (2000) merupakan "kondisi yang aman atau selamat dari penderitaan dan kerusakan atau kerugian di tempat kerja berupa penggunaan mesin, peralatan, bahan-bahan dan proses pengolahan, lantai tempat bekerja dan lingkungan kerja, serta metode kerja. Resiko keselamatan kerja dapat terjadi karena aspek-aspek dari lingkungan kerja yang dapat menyebabkan kebakaran, sengatan aliran listrik, terpotong, luka memar, keseleo, patah tulang serta kerusakan anggota tubuh, penglihatan dan pendengaran”.

Masih menurut Magginson dalam Mangkunegara (2000) pengertian kesehatan kerja merupakan kondisi yang bebas dari gangguan secara fisik dan psikis yang disebabkan oleh lingkungan kerja. Resiko kesehatan dapat terjadi karena adanya faktor-faktor dalam lingkungan kerja yang bekerja melebihi periode waktu yang ditentukan dan lingkungan yang menimbulkan stress atau gangguan fisik. Sumakmur dalam Yani (2012) berpendapat kesehatan kerja adalah spesialisasi dalam ilmu kesehatan/kedokteran beserta praktiknya yang bertujuan agar pekerja/masyarakat memperoleh derajat setinggi-tingginya baik fisik, mental maupun sosial, dengan usaha preventif dan kuratif, terhadap penyakitpenyakit atau gangguan-gangguan kesehatan yang diakibatkan oleh faktor-faktor pekerjaan dan lingkungan kerja dan terhadap penyakit-penyakit umum. Pendapat lain oleh Widodo (2015), menyebutkan kesehatan kerja merupakan suatu kondisi kesehatan yang bertujuan agar masyarakat pegawai mendapatkan derajat kesehatan setinggi-tingginya, baik jasmani, rohani dan social dengan usaha pencegahan dan pengobatan terhadap penyakit atau 
gangguan kesehatan yang diakibatkan oleh pekerjaan dan lingkunghan kerja maupun penyakit umum.

Menurut pendapat Sedarmayanti (2014) terdapat dua program kesehatan, yaitu:

1. Kesehatan kerja

2. Kesehatan mental. Dalam rangka menyelenggarakan kesehatan mental, hal yang perlu dilaksanakan adalah:
a. Menyediakan psikiatris untuk konsultasi
b. Bekerja sama dengan psikiatris di luar perusahaan atau di lembaga konsultasi.
c. Mendidik pegawai mengenai arti pentingnya kesehatan mental.
d. Mengembangkan dan melihara program human relation yang baik dll.

Menurut Kamus Bahasa Indonesia dalam Widodo (2015) keselamatan dan kesehatan kerja adalah suatu kondisi kerja yang terbebas dari ancaman bahaya yang mengganggu proses aktivitas dan mengakibatkan terjadinya cedera, penyakit, kerusakan harta benda serta gangguan lingkungan. Menurut OHSAS dalam Widodo (2015) mendefinisikan keselamatan dan kesehatan kerja sebagai kondiri dan factor yang mempengaruhi keselamatn dan kesehatan pegawai, tamu atau orang lain di tempat kerja. Sehingga dapat disimpulkan bahwa keselamatan dan kesehatan kerja merupakan program yang dipakai untuk menjamin keselamatan dan kesehatan bagi pegawai selama bekerja.

Pendapat Sedarmayanti (2014), pada dasarnya, keselamatan dan kesehatan kerja menekankan hal-hal sebagai berikut:

1. Setiap karyawan berhak memperoleh jaminan atas keselamatan kerja agar terhindar dari kecelakaan.

2. Setiap karyawan yang berada di tempat kerja harus dijamin keselamatannya.

3. Tempat pekerjaan dijamin selalu dalam keadaan aman.

\section{Problema dalam Keselamatan dan Kesehatan Kerja}

Kejadian yang sering dialami pegawai yang berhubungan dengan K3 menurut Widodo (2015), dapat dikelompokkan dalam tiga kategori yaitu pertama; berupa gangguan pada lingkungan kerja. Gangguan pada lingkungan kerja misalnya berupa panas, tekanan, getaran, radiasi, suara, kontaminasi dan gangguan kulit. Kedua; ganggaun mental, misalnya kebiasaan minum-minuman keras dan stress. Ketiga; gangguan kecelakaan yang muncul sebagai akibat teknis, akibat manusia, akibat lingkungan atau akibat kombinasi dari teknis, manusia dan lingkungan.

Menurut pendapat Sedarmayanti (2014) terdapat beberapa faktor sebagai penyebab terjadinya kecelakaan kerja, baik dari aspek penyakit akibat kerja maupun kecelakaan kerja. Faktor-faktor tersebut yaitu:

1. Faktor fisik, meliputi penerangan, suhu udara, kelembaban, cepat rambat udara, suara, vibrasi mekanis, radiasi, tekanan udara dan lain-lain.

2. Faktor kimia, berupa gas, uap, debu, kabut, asap, awan, cairan dan benda padat.

3. Faktor biologi dari golongan hewan dan tumbuhtumbuhan

4. Faktor fisiologis, seperti konstruksi mesin, sikap dan cara kerja.

5. Faktor mental psikologis, susunan kerja, hubungan diantara di anatara karyawan ataui dengan pengusaha, pemeliharaan kerja, dan sebagainya.

\section{Pentingnya Manajemen Keselamatan dan Kesehatan Kerja}

Manajemen Keselamatan dan Kesehatan Kerja berupaya untuk mewujudkan dan mengembangkan proses industrialisasi terutama untuk merealisasikan kesejahteraan pekerja. Tujuan Manajemen Keselamatan dan Kesehatan Kerja (Yani: 2012) adalah:

1. Sebagai alat untuk mencapai derajat kesehatan tenaga kerja yang setinggi-tingginya, baik buruh, petani, nelayan, pegawai negeri, atau pekerja-pekerja lepas.

2. Sebagai upaya untuk mencegah kecelakaan dan memberantas penyakit dan kecelakaan-kecelakaan akibat kerja, memelihara, dan meningkatkan kesehatan dan gizi para tenaga kerja, merawat dan meningkatkanb efisiensi dan daya produktivitas tenaga manusia, memberantas kelelahan dan melipatgandakan gairah serta kenikmatan manusia.

Menurut Sedarmayanti (2014) tujuan Manajemen Keselamatan dan Kesehatan Kerja adalah:

1. Sebagai alat mencapai derajat kesehatan tenaga kerja setinggi-tingginya, baik buruh, petani, nelayan, pegawai negeri atau pekerja bebas.

2. Sebagai upaya mencegah dan memeberantas penyakit dan kecelakaan akibat kerja, memelihara, meningkatkan efisiensi dan daya produktivitas tenaga manusia, memberantas kelelahan kerja dan melipatgandakan gairah serta kenikmatan bekerja.

3. Memberikan perlindungan bagi masyarakat sekitar perusahaan, agar terhindar dari bahaya pengotoran bahan proses industrialisasi yang bersangkutan, dan perlindungan masyarakat luas dari bahaya yang mungkin ditimbulkan oleh produk industri

Pendapat Widodo (2015) menyebutkan tujuan Keselamatan dan Kesehatan Kerja (K3) adalah untuk memelihara kesehatan dan keselamatan lingkungan kerja. 
Dalam hal ini K3 juga berupaya melindungi rekan kerja, keluarga pegawai, konsumen, dan orang lain yang mungkin terpengaruh pada kondisi lingkungan di tempat kjerja.

Menurut Rachman dalam Widodo (2015) tujuan umum K3 adalah menciptakan tenaga kerja atau pegawai yang sehat dan produktif, dengan rincian sebagai berikut:

1. Agar tenaga kerja dan setiap orang berada di tempat kerja selalu dalam keadaan sehat dan selamat

2. Agar sumber-sumber produksi dapat berjalan secara lancer tanpa adanya hambatan

Sasaran yang akan dicapai dengan adanya manajemen keselamatan dan kesehatan kerja adalah:

1. Tumbuhnya motivasi untuk bekerja secara aman.

2. Terciptanya kondisi kerja yang tertib, aman dan menyenangkan.

3. Mengurangi tingkat kecelakaan di lingkungan kantor.

4. Tumbuhnya kesadaran akan pentingnya makna keselamatan kerja di lingkungan kantor.

5. Meningkatnya produktivitas kerja (Sedarmayanti: 2014).

\section{Manfaat Manajemen Keselamatan dan Kesehatan Kerja}

Banyak manfaat yang diperoleh dalam penerapan Manajemen K3. Menurut Yani (2012), manfaat tersebut adalah sebagai berikut :

1. Perlindungan bagi tenaga kerja

2. Menunjukkan adanya kepatuhan dalam peraturan dan undang-undang

3. Menghemat biaya

4. Membuat sistem manajemen yang efektif

5. Meningkatkan kepercayaan dan kepuasanan pelanggan

Pendapat lain oleh Ramli (2009) manfaat K3 bisa dilihat dari bermacam sisi yaitu :

1. Sisi hukum.

Berdasar sisi hukum, terdapat banyak peraturan perundanga yang menyangkut K3. Beberapa diantaranya

a. Undang-Undang No.1 Tahun 1970 tentang Keselamatan Kerja

b. Undang-Undang No. 13 Tahun 2003 tentang Ketenagakerjaan

c. Undang-Undang No. 8 Tahun 1998 tentang Perlindungan Konsumen

d. Undang-Undang No. 19 Tahun 1999 tentang Jasa Konstruksi

e. Undang-Undang No. 28 Tahun 2001 tentang Bangunan Gedung f. Undang-Undang No. 30 Tahun 2009 tentang Ketenagalistrikan

\section{Perlindungan tenaga kerja}

Keselamatan dan Kesehatan Kerja mempunyain arti melindungi tenaga kerja dari kecelakaan atau penyakit akibat kerja. Perlindungan tenaga kerja meliputi jaminan social, jam kerja, upah minimum, hak berserikat dan berkumpul serta perlindungan kelesalamatannya.

\section{Aspek ekonomi}

Manfaat lain dari adanya K3, bias dilihat dari aspek ekonomi. Seperti diketahui apabila tenaga kerja mengalami kecelakaan, maka instansi/perusahaan akan mengalami kerugian yang tidak sedikit, disebabkan biaya yang harus dikeluarkan untuk mengobati tenaga kerja tersebut. Dampak ekonomi menurut Ramli (2009) dapat dilihat dari dua sudut yaitu:

a. K3 dan Produktivitas

Produktivitas instansi/perusahaan akan dipengaruhi oleh adanya kecelakaan. Produktivitas dipengaruhi oleh kuantitas, kualitas dan keselamatan. Ketiga unsur tersebut harus berjalan dengan seimbang. Dalam arti produktivitas tidak akan tercapai jika hanya mengutamakan kualitas dan kuantitas saja, dan tidak memperhatikan keselamatan kerja.

b. K3 dan Pengendalian Kerugian

K3 juga mempunyai hubungan dengan pengendalian kerugian. Hal ini dikarenakan K3 tidak hanya meliputi kecelakaan atau cedera yang dialami tenaga kerja, tetapi juga menyangkut sarana produksi dan asset dari instansi/perusahaan. Apabila terjadi kecelakaan pada tenaga kerja, kebakaran dan kerusakan material,maka instansi/perusahaan akan mengalami kerugian. Hal ini akan berdampak kerugian pada aspek ekonomi dalam instansi/perusahaan

Dalam upaya menerapkan Manajemen Keselamatan dan Kesehatan Kerja, instansi atau perusahaan memiliki pedoman sebagai berikut:

1. Menetapkan kebijakan keselamatan dan kesehatan kerja dan menjamin komitmen terhadap pnerapan system manajemen $\mathrm{K} 3$.

2. Merencanakan pemenuhan kebijakan tujuan dan sasaran penerapan keselamatan dan kesehatan kerja.

3. Menerapkan kebijakan keselamatan dan kesehatan kerja secara efektif dengan mengembangkan kemampuan dan mekanisme pendukung yang diperlukan mencapai kebijakan, tujuan, sasaran, keselamatan dan kesehatan kerja. 
4. Meninjau secara teratur dan meningkatkan pelaksanaan sistem manajemen K3 secara berkesinambungan dengan tujuan meningkatkan kinerja keselamatan dan kesehatan kerja (Sedarmayanti: 2012)

Syarat keselamatan kerja tercantum dalam UndangUndang Nomor 1 tahun 1970 tentang Keselamatan dan Kesehatan Kerja yang terdiri dari:

1. Mencegah dan mengurangi kecelakaan.

2. Mencegah, mengurangi dan memadamkan kebakaran.

3. Mencegah dan mengurangi bahaya peledakan.

4. Memberi kesempatan atau jalan menyelamatkan diri pada waktu kebakaran atau kejadian yang berbahaya.

5. Memberi pertolongan pada kecelakaan.

6. Memberi alat perlindungan diri pada karyawan.

7. Mencegah dan mengendalikan timbulnya atau menyebarluasnya suhu, kelembaban, debu, kotoran, asap, uap, gas, hembusan angin, cuaca, sinar laut atau radiasi, suara dan getaran.

8. Mencegah dan mengendalikan timbulnya penyakit akibat kerja baik fisik maupun psikis, keracunan, infeksi dan penularan.

9. Memperoleh penerangan yang cukup dan sesuai.

10. Menyelenggarakan suhu udara yang baik dan cukup.

11. Memelihara kebersihan, kesehatan, ketertiban.

12. Memperoleh keserasian antara proses kerja.

13. Mengamankan dan memperlancar pengangkutan orang, binatang, tanaman atau barang.

14. Mengamankan dan memperlancar segala jenis bangunan.

15. Mengamankan dan memperlancar pekerjaan "bongkar muat, perlakuan dan penyimpanan barang".

16. Mencegah terkena aliran listrik.

17. Menyesuaikan dan mnyempurnakan pengamatan pada pekerjaan yang bahaya kecelakaannya menjadi bertambah tinggi.

\section{Langkah-Langkah Penerapan Keselamatan dan Kesehatan Kerja}

Manajemen

Pimpinan dan tenaga kerja perlu memahami tentang manajemen K3. Berkaitan denga hal tersebut, maka berikut ini tentang tahapan dan langkah-langkah dalam penerapan manajemen K3. Tahap dan langkahlangkah tersebut menurut Yani (2012) adalah sebasgai berikut:

1. Tahap Persiapan

Pada tahap ini merupakan langkah awal yang harus dilaksanakan oleh instansi/perusahaan. Langkah-langkah tersebut melibatkan pimpinan dan sejumlah personil, mulai dari yang menyatakanb komitmen sampai pada personil yang menentukan sumber daya yang diperlukan. Tahap persiapan ini yaitu:
a. Komitmen pimpinan puncak
b. Menentukan ruang lingkup
c. Menetapkan cara penerapan
d. Membentuk kelompok penerapan
e. Menetapkan sumber daya yang diperlukan

2. Tahap Pengembangan dan Penerapan

Pada tahap ini merupakan langkah-langkah yang dilaksanakan oleh instansi/perusahaan dengan melibatkan banyak personil, mulai dari yang menyelenggarakan penyuluhan dan melaksanakan audit internal dan tindakan perbaikan sampai melakukan sertifikasi. Adapun langkah-langkah tersebut adalah:
a. Menyatakan komitmen
b. Menetapkan cara penerapan
c. Membentuk kelompok kerja penerapan
d. Menetapkan sumber daya yang diperlukan
e. Kegiatan penyuluhan
f. Peninjauann sistem
g. Penyusunan jadwal kegiatan
h. Pengembangan manajemen K3
i. Penerapan sistem
j. Proses spesifikasi

Harapannya dengan memahami tahap dan langkahlangkah tersebut, maka instansi/perusahaan dapat menerapkan manajamen keselamatan dan kesehatan kerja.

\section{Manajemen Keselamatan dan Kesehatan Kerja dalam Mewujudkan Zero Accident}

K3 merupakan upaya praktis untuk memberikan jaminan keselamatan dan meningkatkan derajat kesehatan bagi pegawai dengan cara melakukan pencegahan terhadap kecelakaan dan penyakit akibat kerja serta pengendalian terhadap bahaya di tempat kerja. Menurut Mangkunegara (2008) K3 mempunyai filosofi sebagai pemikiran dan upaya untuk menjamin keutuhan dan kesempurnaan jasmani dan rohani pegawai pada khususnya dan manusia pada umumnya, hasil karya dan budaya menuju masyarakat makmur dan sejahtera.

K3 merupakan upaya perlindungan terhadap semua potensi yang dapat mengakibatkan bahaya. Hal ini mendorong pentingnya K3 ditanamkan pada diri para pegawai, bahkan perlu diberikan hukuman bagi pegawai yang tidak memakai alat-alat pengaman (seperti masker, sarung tangan, tutup mulut, dan hidung) saat bekerja. K3 merupakan tindakan kontrol preventif yang mendorong terwujudnya pemeliharaan pegawai yang baik (Hasibuan, 2012). Menurut pendapat Fathoni dalam Widodo (2015) semua pegawai diharapkan mendapat pendidikan dan 
pelatihan serta bimbingan dalam K3 dengan ketentuan yang dibuat sebagai berikut:

1. Mengeluarkan peraturan-peraturan yang berhubungan dengan $\mathrm{K} 3$ pegawai

2. Menerapkan program kesehatan kerja bagi pegawai

3. Menerapkan system pencegahan kecelakaan pegawai

4. Membuat prosedur kerja

5. Membuat petunjuk teknis tentang pelaksanaan kerja termasuk penggunaan sarana dan prasarana

Instansi juga perlu melaksanakan suatu usaha untuk memberi kesadaran kepada pegawai tentang betapa pentingnya untuk ikut mewujudkan terlaksananya K3 di tempat kerja. Dengan setiap pegawai mewujudkan program K3, maka pegawai akan terhindar dari kecelakaan kerja, yang memberikan dampak bagi instansi yaitu terciptanya ketenangan dan kemajuan instansi.

\section{PENUTUP}

\section{Simpulan}

K3 merupakan upaya praktis untuk memberikan jaminan keselamatan dan meningkatkan derajat kesehatan bagi pegawai dengan cara melakukan pencegahan terhadap kecelakaan dan penyakit akibat kerja serta pengendalian terhadap bahaya di tempat kerja. Adanya Kesehatan dan Keselamatan Kerja pada setiap instansi akan menciptakan terwujudnya pemeliharaan pegawai yang baik. Hal tersebut dapat dilakukan melalui pendidikan dan pelatihan yang diikuti oleh pegawai serta bimbingan dalam K3 dengan ketentuan mengeluarkan peraturan-peraturan yang berhubungan dengan $\mathrm{K} 3$ pegawai, menerapkan program kesehatan kerja bagi pegawai, menerapkan sistem pencegahan kecelakaan pegawai, membuat prosedur kerja, dan membuat petunjuk teknis tentang pelaksanaan kerja termasuk penggunaan sarana dan prasarana.

\section{Saran}

Dalam upaya memenuhi kebutuhan akan perlindungan bagi tenaga kerja dari kecelakaan dan penyakit akibat kerja serta pengendalian terhadap bahaya di tempat kerja, maka instansi perlu memperhatikan keselamatan dan kesehatan tenaga kerja dengan menerapkan Manajemen Keselamatan dan Kesehatan Kerja (K3) termasuk memberikan kesadaran kepada pegawai tentang pentingnya $\mathrm{K} 3$ di tempat kerja.

\section{DAFTAR PUSTAKA}

\footnotetext{
Alwi, Syafaruddin. 2001. Manajemen Sumber Daya Manusia Strategi Keunggulan Kompetitif. Yogyakarta: BPFE
}

Hasibuan, Malayu, S.P. 2012. Manajemen Sumber Daya Manusia. Jakarta: Bumi Aksara

Mangkunegara, Anwar Prabu. 2008. Manajemen Sumber Daya Manusia Perusahaan. Bandung: Remaja Rosdakarya.

Moekijat. 2010. Manajemen Sumber Daya Manusia. Bandung: Mandar Maju

Ramli, Soehatman. 2010. Sistem Manajemen Keselamatan dan Kesehatan Kerja. Jakarta: Dian Rakyat

Sedarmayanti. 2014. Manajemen Sumber Daya Manusia Reformasi Birokrasi dan Manajemen Pegawai Negeri Sipil. Jakarta: Refika Aditama

Widodo. 2015. Manajemen Pengembangan Sumber Daya Manusia. Yogyakarta: Pustaka Pelajar

Yani. 2012. Manajemen Sumber Daya Manusia. Jakarta: Mitra Wacana Media 